\title{
Globalisation
}

\section{Sikander Rahim}

\begin{abstract}
The crisis in East Asia has tempered the loud enthusiasm of many economists, magazines and multilateral institutions for unbridled international flows of capital. Since its start some prominent economists and financiers have expressed doubts that market mechanisms, left to themselves, necessarily end with a desirable outcome. Perhaps this is the first step to questioning whether free flows of capital between countries are desirable at all.
\end{abstract}

Oddly enough, despite all that has been written in textbooks and journals extolling international capital flows and all the romanticisation of 'globalisation' in television advertisements, there appears to be no systematic examination of the gains and losses to be expected from them. One reason may be that economic theory, as it stands now, is ill suited to carrying out such an examination. International economic theory has two strands, the one to explain how trade in finished products and raw materials is determined by comparative advantages and the other, using quite separate assumptions, to explain the balance of payments. In the former it is assumed that capital flows are negligible, in the latter they do little more than accommodate trade imbalances. Neither address the question of what determines capital movements or what their effects might be.

Another reason may be that the success of certain East Asian economies over the last two decades was to a great extent the result of or at least made possible by foreign direct investment (FGI). Seeing how few successes there had been in economic development over the last half century, economists, especially development economists, were not inclined to be critical. The owners and managers of capital had even less motive to ask questions; it was, after all, their freedom of action that was being enlarged. It is also they who have the most influence over the media and, consequently, over the public's views. Such dissent as has been expressed has come mainly from labour movements and left wing circles, whose influence over the media and policy is not great, though the distinction between the effects of trade and those of capital flows is rarely made.

A number of basic questions can be asked about capital flows. To the most basic one, what are their determinants, there is as yet no satisfactory answer. It is a matter of observation that the simple formula so often put forward, sound macroeconomic policies, is neither necessary nor 
sufficient, though such policies are sure to be helpful. The next question is, from whom and to whom does capital flow? It makes a great difference whether one speaks in net or gross terms. Developing countries are most concerned with net flows and the net sources of capital are a few European countries and Japan. By far the largest net absorber of capital is the US, although it is one of the biggest sources in gross terms. Of what remains, China has been absorbing about a third and some ten other countries almost all the rest. What are the gains and losses for different countries and social groups? If the conditions are right, FDI and long term loans bring jobs and income to the recipient country. But it seems logical to suppose that they must then have the opposite effect in the source country. FDI, in particular, by creating productive capacity and jobs in the host country implies investment, and therefore jobs and income foregone in the source country. The high rates of unemployment in Europe are more likely to be the effects of capital outflows than the stringency of the Maastricht targets. Portfolio capital seems to offer no benefit to the recipient country compatible with prudent macroeconomic management, if it is regarded as severing the link between savings and investment, as advised by the World Bank, that is imprudent management. Can capital movements be controlled? Despite all that has been said and written to prove that they cannot, controlling them is not difficult and many countries apply their controls quite effectively. It is true that some capital escapes and that corruption can render controls ineffective, but that is true of most laws.

\section{The Meaning of Globalisation}

The growing mobility of financial capital is one of three distinct trends that have interacted to enhance each other and are comprised under the broader term 'globalisation'. Of the other two, one is the dispersion by enterprises of their production capacities over different economies, with the output going to yet other destinations. The other is the rise in the speed and ease and the fall in the cost of transmitting information around the world. It is the interaction of these three trends that has given present day globalisation its special character.

The dispersion of production has been rendered possible by declining costs of transport and packaging, which have multiplied the opportunities for reducing the costs of goods by distributing the production of different components or the different stages of the production process over different economies. This trend first became significant in the 1960s, when the European subsidiaries of US motorcar manufacturers began to supply each other with components, but it has since then been especially pronounced with the products that have been most prominent in East Asia's development, apparel and electronics, where the relatively high value in 
relation to bulk has made the costs of transporting work in progress or components count for little in total costs. The different stages in the making of a business suit, design, weaving of the cloth, cutting and assembly, can be spread over different countries and often are. Similarly, the various components of an electronic apparatus may be produced in different locations and assembled in yet another place.

The consequence has been that international trade has grown in a manner orthodox theory did not anticipate and has found hard to accommodate, though it is not necessarily in conflict with the facts. The proportion of trade in manufactures that is actually delivery between subsidiaries of the same firm (intra-firm trade) is estimated to have grown to about 30 per cent of all international trade. In contrast, the theory had always been couched in terms of final products and their ultimate markets. There were two reasons for this. One was that it was implicitly assumed that the costs of transport and trade barriers were too great for firms to disperse the production of a good over different countries. The second was that a basic assumption of orthodox trade theory has been that international flows of capital are insignificant, whereas this dispersion has been largely the result of foreign direct investment. The main implications for theory have been that the flow of capital, and therefore comparative advantages, have become consequences of the extent to which the production of goods can be broken down into discrete components and stages and the costs of transport, and that the explanation of the pricing of goods produced and used by the same firm is, to some extent, detached from the actual costs of production and comparative advantages by complications such as the effects on transfer pricing of taxes and financial structure.

Dispersion of production has been helped by advances in the transmission of information. Along with the ease of maintaining contact through oral communication, with better telephone links and devices like cellular telephones, the transmission of data in numerical and graphical form has become instant and cheap. Thus, the design of a business suit and the weave of the cloth can be prepared in one place and transmitted by satellite to distant countries. The same methods have made common the dispersion of numerous services, such as the processing of airline reservations or insurance claims. Travel has also become cheaper, faster and simpler; the comfort and needs of the business traveler are catered to by major industries that are, in themselves, examples of globalisation.

\section{International Capital Flows and their Consequences}

Since the late 1970s, gross private international financial flows have been growing much faster than anyone would have predicted in the early 
1970s and a considerable part of the growth has consisted of movements on the capital account. Much of the success of the developing East Asian countries, Thailand, Malaysia and Indonesia, is attributable to their inflows of foreign private capital and it has given rise to the widely held belief that similar success was within the grasp of other developing countries that emulated these countries in managing their macro-economic balances prudently, opening their economies to trade and foreign capital and confining the government to necessary activities that the private sector could not perform.

\section{Flows to the Developing Countries}

\section{Which countries benefit? Not many}

But, however fast capital flows have been growing, there are at any time limits to the net amounts that can flow out of the capital exporting economies, essentially a few European countries and Japan. Countries importing capital must, therefore, compete for it and the competition is more intense the closer the amounts come to these limits. The winner, by a long margin, has been the US, whose annual current account deficit has averaged over US\$ 115 billion since 1984 and is expected to approach US\$ 300 billion in 1998. In comparison, the cumulative net flow of long term capital to developing countries (excluding Korea) from 1990 to 1996 is estimated to have been almost US\$ 950 billion; the estimate for foreign direct investment over the period 1990-97 being US\$ 595 billion [World Bank (c)]. In 1996 long term capital flows to developing countries (including Korea) are estimated to have been US\$ 265 billion.

The result of the competition has been that the distribution of the capital flows has been skewed. For instance, 80 per cent of the long term flows from 1990 to 1995 went to 12 countries, including Russia and Hungary, and one third of the total from 1990 to 1996 went to China [World Bank (a)]. It is not evident that these countries have better records as regards macro-economic prudence, openness or limits to government activity than many countries that have tried and failed to attract foreign investors on a large scale. More comprehensive data would probably show still greater skewness; although the figures given here for long term capital are for net flows, they disregard many forms of capital flight, which have been considerable from Latin America, Africa, South Asia and the former Soviet Union. And the picture would be even worse if the return home of flight capital, especially of the wealth held abroad by nationals of Latin American countries resident in their home countries, were to be excluded from the flows to the developing countries. 


\section{What are the benefits to the developing countries? FDI}

The economic consequences for a developing country of foreign capital inflows depend on the form that the inflows take. The customary distinction is between foreign direct investment (FDI) and portfolio capital. FDI occurs when productive capacity is set up in the host country with foreign equity financing. The host country incurs no obligation on the financing of the capacity, though it will have an obligation to allow the repatriation of earnings. Portfolio investment comprises everything else by which foreign capital is brought into the host country, including bank loans, bonds, purchases of equity in the host country's enterprises, short term loans and bank deposits in the host country. Global and American depository receipts, although usually classified as portfolio investment, can partake of the character of FDI when used to finance new productive capacity in the host country.

FDI is the form most sought after by developing countries since it results directly in increased productive capacity. It also has little immediate net effect on the balance of payments, since it consists largely of financing of plant and equipment which are imported. So it creates no discernible pressure on the exchange rate. If the investment is in an export activity or one that is not highly protected against competition, there is a net income gain to the economy, even if gross profits are repatriated. But if it is in a highly protected activity, the profit repatriated may be greater than the economic gain. Because of this, highly protected economies such as Pakistan and India until fairly recently, have tried to control foreign investments.

FDI also brings indirect benefits, through externalities. One of them is that it often increases the host country's stock of technical and management skills. When a firm from a developed country makes a direct investment in a developing country, it often employs more advanced technology and management practices than the firms of the host country are likely to have and it trains the locally hired employees in them. The training may be limited, but it can also be substantial, including sending the locally hired staff to the parent company's other units or to its own training facilities. Such training can consist both of basic training and frequent updating courses. A second externality is that the foreign investment can create opportunities for backward links, whereby other firms in the host country supply it with inputs. In combination, these two externalities have been the stimulus to considerable industrial growth in East Asia. Japanese firms, in particular, invested heavily in the training of their employees, and set up subsidiaries as suppliers of inputs for their initial investments. The 
pattern of US firms appears to have been to encourage the development of local suppliers (Gereffi in Campbell, Parisotto, et al.).

But the opportunity for backward linkage depends on the degree to which the foreign firm integrates into the host economy. It frequently happens that the incentives offered to foreign firms to make a direct investment in the country ensure that they will not be subject to the ordinary difficulties and costs faced by local businesses. Thus they may get special tax treatment and benefit from simplified procedures for customs and foreign exchange. If, then, a local firm wishes to supply inputs, it must compete with the foreign firm's ability to import easily and free of duty, while it, itself, faces the difficulties of which the foreign firm has been relieved. Consequently, arrangements such as EPZs in Mexico, Tunisia and Malaysia are observed to result in little linkage (Gereffi in Campbell et al.). The firms in them import their inputs and export their outputs, usually confining themselves, like many Mexican maquilladoras, to simple assembly operations. This may be one reason why the World Bank finds the indirect effects of FDI "hard to pin down". [World Bank (c). See also Aitken and Harrison]

What are the benefits to developing countries of inflows of portfolio capital? It can cause macro-economic problems and it is a dangerous way to finance current account deficits

Portfolio investment's advantages to the host country are more doubtful. In theory it "severs the link between savings and investment" [World Bank (c), e.g. pp. 23 and 165] but, in practice the conditions for that to work are rarely found in developing countries. Consequently, it is often not welcomed by the authorities of these countries. It poses three problems, especially grave when it comes in waves. It creates the base for an expansion of the money supply, it puts pressure for appreciation of the foreign exchange value of the currency and it requires that the resources for accommodating an outflow be immediately available.

To the extent that an inflow of portfolio investment accommodates the financing of a deficit on the current account, it does not add to reserves, which may, therefore, not suffice to allow foreign investors to withdraw more than a fraction of the foreign exchange they brought in. in this case, if a crisis is to be avoided, the investors must be persuaded to retain their confidence, even though they are aware that were there to be a broad movement out of the currency, the first out would come off best. This is the situation that developed in Mexico in 1994, in Thailand in May 1997 and in Malaysia, Indonesia and Korea in the following months. Their currencies fell sharply, in contrast to Hong Kong, Singapore and Taiwan, all 
with substantial reserves, which were able to maintain comparatively stable exchange rates. The advice sometimes given, that an economy should hold more international reserves if investor confidence in it is not high, is of little use; reserves take years to build up, whereas confidence can change in days or weeks.

The first to foresee an impending crisis of this kind are likely to be those with the best connections with political leaders and the highest rungs of the administrative system, and these will usually be nationals, not foreigners. Thus, in the Mexico crisis in 1994 the flight of capital began with Mexicans (IMF 1994). It was to be expected, since much of the financing of the deficits of the previous years had been Mexican flight capital returning to take advantage of high interest rates and its owners were likely to be both acutely aware of the risks and well informed. Mexican capital flight during 1981-91 has been estimated by World Bank staff at around US\$ 3 billion a year, roughly the same as for Argentina and Brazil. However, other sources estimate the stock of Mexican flight capital rather higher than the cumulative flow referred to here. Flight capital may have been less important in the case of Thailand, but again much of the capital to move out first seems to have belonged to permanent residents. Once the outflow has started, foreign investors, bankers and mutual fund managers aggravate it, but by then they have mostly made losses, unless they hold foreign currency debt that is honoured or rescheduled later.

\section{It may be desirable to sterilise foreign portfolio capital if it cannot be deterred}

To the extent that a portfolio capital inflow does not finance a current account deficit, the authorities can accommodate it with policies ranging anywhere between not changing the money supply, i.e. sterilisation, and letting it expand to absorb all the inflow, or they can try to deter it. Various combinations of these policies have been tried by different economies.

Complete sterilisation results in an accumulation of foreign exchange reserves equivalent to the inflow and raises the basic question as to why an economy should wish to have an inflow of portfolio capital if it has to keep it in the form of reserves, especially since the yield on reserves is likely to be lower than the yield on the investments of the foreign investors. There can be other undesirable effects too. It may be impossible to prevent a substantial appreciation of the currency and a consequent tendency to recession, as happened to Switzerland in 1996, when there was a large inflow of German funds. 
Mechanisms for sterilisation have their own drawbacks; open market operations raise interest rates, incidentally encouraging more inflows, whereas other methods cause fluctuations and uncertainties in the financial market of the host country through their effects on bank reserves, interest rate differentials, deposit movements or taxes (IMF). At the other extreme, allowing the money supply to expand freely in response to the inflow of portfolio capital results in a combination of current account deficits and inflation in the prices of goods, financial assets and property. Current account deficits raise concerns that have already been discussed, while the inflationary effects of monetary expansion are likely to be interpreted as symptoms of imprudent macro-economic management and may also cause a loss of confidence. In that case there will not be enough reserves to accommodate a rapid withdrawal. Some countries (e.g. Thailand) have off-set inflows by encouraging outflows or have used swaps to achieve the same result (Indonesia), losing, to the extent they are successful, whatever advantage the inflow is supposed to bring and incurring the additional risk that they may not be able to convert their foreign assets in time to accommodate an eventual outflow.

If the authorities prefer to deter portfolio capital inflows, they have a wider choice of instruments the less they are committed to free movements of capital. During the period of the Bretton Woods system of fixed exchange rates, Germany introduced taxes on the earnings from German securities held by non-residents as a means of deterring speculative inflows occasioned by expectations of a revaluation of the German mark or a devaluation of the Sterling or the French frank. More drastic measures would have been against the spirit of liberalisation of capital movements that was then taking place under the auspices of the OECD. More recently, funds flowing into Switzerland from Germany, on account of apprehension over the impending currency union, have caused the Swiss frank to appreciate. The Swiss authorities considered the appreciation excessive and have been concerned that it might start a recession, but, because of Switzerland's position as an international banking centre, the only deterrent they dispose of is a low interest rate.

Countries that are less committed to the freedom of capital flows have more effective methods at their disposal. Methods of adding costs to portfolio capital flowing in range from taxes on interest or transactions to the obligation to deposit part of the money without remuneration. Chile's method of requiring part of the capital to be deposited for a specified time, say a year, has the additional advantage of being selective: longer term investments are deterred less than short term inflows. Some countries that peg their exchange rates have broadened the bands in which their currencies trade to increase the uncertainties. Since this also creates 
uncertainties for the domestic economy and, thereby reduces the advantage of the peg, it seems a high price to pay for something one does not want. If a country does not want portfolio capital coming in and has effective capital controls, the simplest and most effective deterrent may be to announce that it will impose restrictions on the outflow of capital.

\section{What are the advantages to developing countries of liberalising their capital accounts? There seems to be no valid argument in its favour}

The liberalisation of capital movements occurred in the developed countries during the 1950s and 1960s and has come to be taken for granted as part of normal business and everyday life. Now a similar liberalisation is expected of those developing countries that have not already taken the step. Leaders and high ranking officials of developed countries have joined institutions such as the IMF and the World Bank in considering the liberalisation of the capital account of a developing country as desirable. Though the IMF has usually been cautious in recommending it, since the conditions for such a step to succeed lastingly are hard to satisfy.

The economic benefits to a developing country from a liberalisation of its capital account are, however, doubtful. Five arguments are to be found to be given as justification, and all can be questioned. One is that markets should be allowed to function freely and a second, related to it, is that allowing resources to move to where they are most productive maximises world welfare. The third argument is that, just as a country should use world prices for goods to reach an optimal allocation of resources, it should use world interest rates. The fourth argument is that a country will not be able to attract foreign capital if it has controls over its capital account. And the fifth is that capital controls do not work in any case. Only the third and fourth arguments refer to the welfare of the country.

The argument that markets should not be hindered is simply a statement of political belief. Its adherents draw the line at allowing labour to move across boundaries with the same freedom as they advocate for capital. It is sometimes supported by the contention that the movement of capital is a substitute for migration [e.g World Bank (d), Chapter 3], though presumably it is not meant to apply to migration from Africa, South Asia or even China. The second argument is much the same, since it equates welfare with output, without regard to where the capital generates employment, and it also excludes international labour movements. It gives no reason to believe that poor developing countries will benefit from a net inflow, rather than an outflow. Instead, it leads to the conclusion that some of the poorest countries, such as those of the Sahel, where the returns on 
investment are low because of difficult physical and climatic conditions, must be content to let their capital flow out. And when a ruling clique or a dictator prefers to place money pillaged from their country in foreign accounts, the banks with which the money is deposited will allocate the resources efficiently from a world-wide point of view, even if none go back to the country of origin.

When the argument is put in terms of access by domestic residents to foreign capital markets and the increase in the pool of investable funds, from which the developing countries are expected to benefit (Fischer), it either ignores the constraint that net capital flows over the whole world are zero (one country's capital inflow is another's outflow), or it assumes that supply of capital from the handful of capital exporting countries of western Europe and Japan is unlimited. Once the US inflow has been allowed for, the amounts available for developing countries may not be that great. Some developing countries are bound to be losers in the competition for foreign capital, meaning that, if their capital accounts are open, they will have net outflows. Both arguments ignore, furthermore, the effects that large outflows of capital can have on the social and economic stability of a country, especially if they continue for a long time. Neither argument would carry much weight with the developed countries if, at any time, the outflow of capital were to threaten their stability. Simplistic though they be, both are regularly put forward.

The third argument, that world interest rates should be used in the same way as the world prices for goods, is a form of economic reasoning, though it rests on two fallacies. One is that interest rates perform the same function as prices of goods. The reasoning that world prices of goods should be used is that goods can be exchanged at these prices through international trade and, hence, their use leads to an optimal allocation of resources at any time. It is not applicable to interest rates, whose importance is intertemporal. If the argument is modified to conclude that capital should be exported if world interest rates are higher than domestic rates, it is merely a repetition of the second argument. The second fallacy is the assumption of the existence of world interest rates, when it is obvious that the developed countries have different interest rates and that these rates do not even move in the same direction at any given time. The fallacy is born from enthusiasm over globalisation and "world markets", which jumps from the supposition that capital flows freely to the supposition that interest rates must be equalised around the world's financial markets. Simple observation would reverse the argument, interest rates are far from equal among developed countries, therefore capital is not completely mobile. 
The fourth argument is also contradicted by experience. Foreign investors were eager to invest in Korea and Taiwan at a time when both exercised capital account controls and were selective about foreign investment. Moreover, many countries have, without abandoning control over their capital accounts, been able to reassure foreign investors that they will not be prevented from taking their funds out. Foreign investors usually prefer such an arrangement to complete liberalisation, since it gives more assurance that the country will not be thrown into a crisis by capital flight, and the recent East Asia experience might have the effect of strengthening this preference.

\section{It is also false that countries have no choice because they cannot control capital flight}

The argument that controls do not prevent capital from escaping is partly correct, but they may, nonetheless, be desirable. They may not prevent gradual outflows, but they can be made adequately effective in most countries to prevent the waves of capital flight that create instabilities, especially when the country has political or economic difficulties. Their drawback in developing countries is that they may add to the incentive for capital to escape. In any country, with the possible exception of the US because of its size and stability, wealthy individuals and firms with substantial liquid assets have an incentive to hold sound assets of other strong economies as a normal part of risk diversification. In developing countries risks tend to be greater and so does the incentive. Hence, if controls hinder assets in escaping in times of trouble, they add to the incentive to have some assets abroad at all times.

But well designed capital controls actually reduce the incentive to keep wealth abroad by reducing the risk of crises induced or aggravated by capital flight and, if a balance of payments crisis occurs, by mitigating the effect on the exchange rate. Even economies with open capital accounts need to be able to have control mechanisms at hand which they can impose quickly and effectively when necessary. The IMF recognises that drastic action of this sort may be justified and has rules to prevent them from being abused. Similarly, the Multilateral Agreement on Investment being negotiated between the OECD countries is expected to make provision for such action under the supervision of the IMF. The problems of Thailand, Malaysia and Indonesia, particularly the falls of their currencies' values, would have been less severe if, when these countries liberalised their capital accounts, they had kept control mechanisms in reserve to be imposed when the capital flight began. The absence of these controls is likely to have the perverse effect of giving a greater incentive in the future to keep wealth abroad. 
Apart from such temporary controls, permanent controls can be effective as well. For this they need to make some allowance for the diversification of assets against risk that the economy's authorities cannot control. It may be prudent, as well, in times of crisis, such as the one afflicting East Asia, for controls may reduce the transfer of wealth to foreigners that often follow from them. Controls on the capital account belong to the category of the many laws and regulations that are desirable even though what they are intended to prevent still occurs frequently. Just as speed limits on vehicles are desirable, although drivers often break them, properly designed permanent controls can reduce the outflow of capital. (Compare Dornbusch)

\section{Effects on Developed Countries of Outflows of Capital}

Along with the discussions of the gains that FDI brings to capital importing countries, there has been considerable debate over the last twenty years over the effect globalisation might have of transferring industrial capacity and, consequently, jobs out of developed countries. Since globalisation brings the labour markets of different countries into indirect competition, at issue is whether or not the workers of developed countries lose from competition. The governments of the developed countries are not likely to let the social strains in their countries caused by globalisation become so great as to lead to economic and social decay, eventually to collapse. Sooner or later, they will take steps to shield their countries, most probably by returning to the protection of their domestic industries against imports from developing countries and to more constraints on people originating from the Third World.

A number of adverse developments in developed countries are frequently blamed on globalisation. Most striking is the high unemployment in most of the EU, which is now several times the levels that had once been considered as the highest compatible with social peace. Even as late as the 1960s, an unemployment rate of 3 per cent was considered dangerously high, now it would be considered wildly optimistic - even dangerously low. Earnings per hour, or week of work of a large part of the workforce in the US have stagnated or declined since the early 1970s, although unemployment is at its lowest level since the 1960s.

Social peace has been kept to some extent, partly because the participation of women in the workforce has increased and has enabled families to mitigate falls in living standards, and partly by the welfare states that these countries, especially in Europe, erected in the post-war years and which have allowed their populations to enjoy unprecedented well-being. But it is uncertain how effectively these mechanisms will continue to 
operate, or for how long. Income inequalities have been rising, notably in the countries with the lowest official unemployment rates. In the UK, the Gini coefficient for incomes, which was 0.36 in 1979 , has risen to 0.43 , roughly at a par with some developing countries. And social peace has not gone unscathed, unemployment and the bleaker prospects for permanent jobs are usually blamed for rising crime rates. Moreover, the higher participation rates of the US, Europe and Japan may be difficult to maintain as their populations age.

The most serious stress on the financial viability of the welfare states of the European countries is their growing costs to the budget. The effects of the ageing of the population on pensions and expenditure for health, on the one hand, and on the tax base, on the other, have been the subject of much analysis and debate. But the possibility must also be taken into account that the present high unemployment in Europe and the ensuing costs of unemployment benefits, may not abate, at least not significantly. Even the more limited welfare system of the US has been experiencing stresses, though the present long run of economic growth has relaxed them for the time being. A recession in the US economy and, as often happens in consequence, in Europe would aggravate stresses that are difficult enough to manage already. It has been pointed out that these welfare systems have been crucial to allowing economies to accommodate the hazards of international trade, the more open the economy the more extensive its welfare system [Rodrik (b)]. The implication is that, if globalisation poses too much strain, the most open economies of Europe will have the most reason to seek shelter behind a European system of trade protection.

International trade and capital flows do not necessarily have the same effects, a distinction that is often lost in using the term "globalisation'. There is no necessity for trade to cause unemployment, since the country that exports acquires foreign exchange that permits it to import to the same value. A form of Say's Law operates between countries. "Hollowing-out', a term that describes a common tendency of developed countries to shift output from industry to services and which is usually attributed to international trade (e.g. Rowthorne, UNCTAD 1996), does not, by itself, imply a loss of jobs.

When jobs are lost because of a loss of demand, it occurs because countries choose to run trade surpluses. The advantages from accumulating large reserves often tempt countries to sterilise some of their export earnings, a renewal of mercantilism that Prof. Joan Robinson warned against in 1966. Even though such reserves are bought dearly, since they are the value of foregone purchases of goods and services, several countries, especially in East Asia, have shown that they are willing to pay the price, 
and the East Asia crisis has shown that the price is worth paying. The deflationary effects of such practices have, however, been offset for some time by the willingness of other countries, notably the US, to accommodate trade surpluses of other countries by running deficits themselves.

Although international trade does not necessarily lead to unemployment, the argument is made that it can do so if factor prices do not adjust as required. According to the orthodox Heckscher-Ohlin theory, when a developed country enters into trade with a developing country and starts with higher quantities of capital per worker and, therefore, higher wages than the latter, free trade will result in lower wages in the developed countries and higher wages in the developing countries. (The theory actually predicts that, when two countries trade, factor prices will be equal, unless a country is completely specialised.) The argument is, then, that it is the resistance to the lowering of wages that causes unemployment in the developed countries. It is an argument often specifically directed at the nonwage costs of labour, notably employer contributions to pensions and insurance, and paid leave. It makes little difference, however, whether the costs are take-home pay or non-wage, both are current costs to the employer and parts of the wage bargain. The question is how far, according to this theory, the total cost of labour, including take-home pay and nonwage costs, must fall to restore full employment. In principle, given the difference between the earnings levels of developed countries and developing countries, the fall could be big.

The theory avoids predicting a big fall (and may allow for factor price equalisation without it) by introducing human capital and technology as factors of production. The acquisition of skills through formal education, specialised training and on-the-job learning has a cost, and becomes human capital embodied in the person, whose productivity is correspondingly raised. By this reasoning, much of what appears to be higher wages is actually a return on human capital. The implications seem far-fetched; thus the unskilled labourer in the US or Europe who earns more than the research scientist in China or Russia must embody more human capital. Sometimes technology is introduced as a separate factor of production that the developed countries have in greater abundance relative to their labour forces than do developing countries, though exactly what is meant by it, let alone how it and its marginal product can be quantified, are not clear.

The effects of foreign investment are more enigmatic since there is no established economic theory for it. The basic assumption of the theories of comparative advantages, that of Ricardo and the Heckscher-Ohlin theory, is that capital does not move in significant amounts. When it does, two views of the consequences can be taken. The more benign view from the 
point of view of the worker of the capital exporting country is that the stock of capital in his country is reduced, or fails to increase, by the amount of capital exported and that his marginal product, hence his wage, falls or fails to rise correspondingly. Thus the effects of trade are augmented. The less benign view is that jobs are transferred to the capital importing country. It was this view that made opposition to the NAFTA an issue in the US election campaign of 1997 and, when unemployment becomes a problem there, as now in Europe, it is a view that may prevail politically.

Two alternative views of the long term effects of the industrialisation of developing countries are possible. One rests on the belief that the comparative advantages of the developed countries are given by their endowments of human capital and technology and that they will, therefore, be able to maintain high earning rates and low unemployment. The other is that the developed countries are faced with the prospects of more unemployment and static, if not declining, earnings for labour. Korea, China and Taiwan, among others, have proved adept at assimilating technology rapidly. The amount of foreign capital they absorb will probably rise rapidly as well. Prospects are that China will absorb capital from developed countries even faster than it has been doing. Bearing in mind that its labour force is as great as the combined labour forces of the US, Europe and Japan, by the time its income levels have risen to more than a small fraction of those of such countries, the volume of its exports and the foreign capital it will have absorbed will be large enough to have had serious effects on employment and earnings of most of the populations of the developed countries. Bring India into the picture and the effects will be even greater. It is doubtful that the developed countries will allow things to go that far.

\section{How has the US been able to reduce unemployment?}

So far the US has been successful in reducing its unemployment rate to the lowest level since the 1960s, while actually increasing the labour participation rate, despite the dire predictions of the opponents of the NAFTA and the WTO. It has enjoyed steady growth with low inflation for seven years and has steadily reduced its budget deficit to the point of running into surpluses. This success does not hold many lessons for other developed countries, since the US is a net capital importer, which most of the others are not. Its ability to grow so consistently with low saving rates stems partly from its freedom, so far, from constraints on its balance of payments, which foreigners have been willing to finance. The combination of low unemployment, low inflation and growing inequalities of income can be attributed to the weakness of its labour movement, which has been able to raise wages only in special cases, such as their successful strike against United Parcel Service. Other efforts since then to raise wages through 
strikes have failed conspicuously because firms could, unlike Federal Express, relocate their production elsewhere, often abroad.

Several reasons can be given why the US attracts so much foreign capital, without their necessarily amounting to a full explanation of a phenomenon that has not been adequately studied and is not well understood. One reason has been the role of the US dollar as reserve currency and international medium of exchange (Bhaduri), a role that has resulted in large net holdings of dollars outside the US. The prime instance of such holdings is the dollar component of the official international reserves of countries (netting out the US holdings of these countries' currencies). Private holdings may be equally important. The dollar has become an accepted medium of exchange in a number of countries other than the US, mainly countries going through political or economic disturbances, and in these and many other countries it is common to hold wealth in the form of dollar bills, especially when there is apprehension about the safety of the domestic currency or there is a motive for concealment. The Federal Preserve Bank of the US mentions that several estimates conclude that at least half of US currency notes are held outside the US, and that this trend has been accelerating in recent years. In 1990 the currency notes outstanding amounted to US\$ 344 billion. (Board of Governors of the Federal Reserve System, p.97)

A second reason has been the attractiveness of US securities, especially fixed interest obligations. As the world's most powerful country, both economically and politically, the US can protect its interests better than any other. Its penchant for low inflation, even if the social costs be high, is well established and inspires confidence in foreigners seeking a safe haven or safe long term investments. And where, as has been the case in Japan, the domestic economy is stagnant and yields on government bonds low, firms and individuals will convert much of their liquid holdings into dollar securities.

A third reason for the inflow of capital to the US has been the desire of many non-US manufacturing firms to establish production capacity there. The motives for doing so are complex, but derive mainly from the size of the US market. Such FDI usually aims to supply the US market, FDI for export from the US is relatively rare. Proximity to the market has some obvious advantages lower transport costs, avoidance of border formalities, closer contact with clients, etc. but fear of trade barriers can also be a strong inducement to transfer production capacity to the market. Tariff barriers have been diminishing the world over, but the response in the US to greater import penetration has been more recourse to NTBs (Trefler), 
Presumably, similar studies for other developed countries would have revealed similar behaviour.

A well known example of an NTB is the voluntary export restraints of Japanese car manufacturers, which allowed the rescue organised by the US government of one of the three major car manufacturers to be successfu1. Mother NTB has been the more frequent use of anti-dumping procedures. These and some political developments, such as the inability, for the moment, of the US president to obtain "fast track' authority for further liberalisation of international trade, especially when there has been a prolonged rise in employment, raise the prospect of more barriers to imports and add to the inducement for non-US firms for which the US is a major market to transfer production there. Industries that must plan far ahead, such as motor car manufacturing, have an especially strong inducement to sateguard their market by setting up plant in the US. They are, moreover, often able to off-set some of the costs by subsidies that states offer in competition with one another to attract the investment.

\section{The Crisis in East Asia}

One effect of the present crisis in East Asia has been to raise the question as to whether the crisis is a natural result of uncontrolled international financial markets or the consequence of the mistaken policies of the affected countries. From the earlier discussion of portfolio investment it can also be argued that the policy mistake might have been to rely on international capital flows. Appearances favour this approach; among the Tier 2 countries, Thailand, Malaysia and Indonesia and, among Tier I countries, Korea had allowed their external current accounts to run into large deficits and the financing was in large part portfolio capital. In Korea's case shor? term borrowing by Korean banks. Once capital started fleeing from Thailand in the Spring of 1997, similar flights from these countries were foreseen by many financiers who had an overall view of their external assets and liabilities.

It is easy to find fault with a country's policies once the country is in difficulties. Thus the World Bank has asserted that the "root causes of the mounting vulnerability of the East Asian countries (the extent of which differed significantly among countries) were financial sector weaknesses and poor corporate governance, macroeconomic conditions and the policy response, and a lack of due diligence by external creditors." [World Bank (a)]. It might seem that such broad terms stand a good chance of catching the true explanation, whatever it might be, but they are too abstract to constitute an explanation in themselves. In 1997, just before the crisis started, the World Bank had argued that sharp changes in the international 
environment had become less likely, that investors and borrowers were more mature, and that one reason for the improvements in credit ratings of the East Asian countries was their strengthening of their banking systems. [World Bank (d)]. To be cogent an explanation must be concrete. (To do the World Bank justice, a few years ago it was unlikely to have been guilty of such superficiality in a published work.)

Two frequently given explanations lay the blame on the policies of the countries and exonerate capital markets. The first is that the currencies had become overvalued with the rise of the US dollar, to which they were pegged, especially in comparison with the Japanese yen after 1995. The inference is that the crisis was the result of fixed exchange rates. It seeks to explain the slowing down of export earnings that occurred between 1995 and 1997. The second is that lack of governance in the affected countries resulted in an accumulation of bad investments.

\section{Exchange rates}

The argument that the exchange rates had become overvalued is post hoc theorising; any overvaluation would have been observable to all, yet no one made the assertion before the crisis. The argument is especially unconvincing since the comparison is with the moment in early 1995 when the dollar had reached its lowest value relative to the Japanese yen and the main European currencies. It also includes the sharp rise of the dollar in the first half of 1997. A longer view leads to different conclusions. Data for real effective exchange rate movements, using the years 1988-92 as the base, are given by the World Bank for Korea, Malaysia, Indonesia, Philippines and Thailand. [World Bank (a)].

These data rule the argument out for Korea, whose currency remained depreciated in real terms for the whole period after 1992, mostly by around 10 per cent. In the case of Thailand, where the crisis started, real appreciation occurred only in 1996 and it had reached about 5 per cent by the end of that year. The same is true for Indonesia. Malaysia had an appreciation that fluctuated between zero and I per cent. The Tier 2 country whose currency appreciated the most was the Philippines, about 15 per cent by the end of 1966 , but it was the least affected by the crisis. It is implausible to infer from these data that the current account deficits were the result of real appreciation of the currencies.

Still more implausible would be to attribute the current account deficits to the real appreciation of about five percentage points, the effect of a sharp rise of the US dollar, that occurred in the first half 1997 for all these countries, apart from Korea. It is possible to try to save the exchange 
argument by arguing instead that expectations were affected, that investors lost confidence as they saw the trend of exchange rates. And there could be some truth to this, though evidence for it has not been put forward. But it is less an argument about real exchange rates than about how expectations can be formed. Moreover, it leaves unexplained the case of Korea.

Going from generalities to specific comparisons with the exchange rates of competitors and markets makes overvaluation seem a still less likely explanation. On the one hand, leaving aside Japan, which competes mostly with the US and Europe, the main competitors of the East Asian economies were themselves. It is, therefore, implausible that they, as a group, were undercut by competitors outside East Asia who allowed their currencies to depreciate. On the contrary, there has been great concern as a result of the crisis that these economies might be indulging in mutually harmful competitive devaluation. On the other hand, arguing that the overvaluation resulted from the depreciation of the yen after 199J fails to explain why the same yen exchange rates had different results before 1995. Equally implausible is the argument that real appreciation caused demand to fall, since that would only have applied to Europe, where demand was rising with the economic recovery.

\section{Governance}

The deficiencies of governance have received much attention since the start of the crisis and they did take their toll on the economies, but they do not seem to provide a good explanation of the causes either. The intertwining of political authority, administrative functions and business interests in the Tier 2 economies has led to much criticism of how investment decisions are made and to terms such as "crony capitalism". Potentially sound ventures get into incompetent hands, investments are undertaken whose benefits are outweighed by the risks and public projects are implemented for imperfectly defined strategic or prestige reasons. Those who make the decisions and stand to gain in the case of success also believe, if they are well connected, that they will escape bearing the losses in case of failure. For instance the banks financing them will roll over the loans indefinitely, transferring the losses to the depositors or, if in danger of becoming insolvent, will be refinanced with the help of the state and transfer the losses to the public. If the investor and the financier believe they are protected in this way, they have an incentive to make insufficient allowance for risk in their decisions and, if it happens frequently, there is a cumulative net loss to the economy, of which little or none falls on those whose decisions caused the loss (Krugman). 
On a sufficiently large scale such behaviour can bring about a crisis. It must result in a decline in the efficiency of the economy and that can lead to the kind of precarious balance of payments that the Tier 2 economies did face before the crisis. Over time, big investment outlays without commensurate returns will either result in a transfer of resources from other uses or an increase in the resource gap and a greater accumulation of external liabilities. In the latter case, the ability of the economy to attract more private external financing will depend on the confidence both of sources of external finance and of the domestic business interests that are able to move their funds out and even speculate against their currency. Confidence may be especially fickle if the liabilities are short term. Scepticism over the future of the economy might also emerge, regardless of the balance of payments, from a sober assessment of the investments taking place, though there is nothing in the behaviour of foreign investors to indicate such foresight.

But it is does not follow that the decline in efficiency resulting from these economically inefficient investments was the basic or underlying cause of the crisis. There is no reason to believe that the slowing of exports that preceded the crisis was the effect of lower economic efficiency. Although many investments, such as manufacturing motor cars or aircraft, big road projects and land speculation were questionable, they do not seem to have been obstructions to exporters. They burdened the banking system with non-performing loans, but the crisis was not initially a banking crisis. The ability of the governments to bail out banks was not in question since none of them faced budgetary problems. Nor did it result in a resource shortage that could have hurt exports since the external current account deficit was being financed by inflows of capital. The outcome would have been no different if the funds spent on questionable investments had instead been spent on consumption, as in Mexico in the period before the crisis occurred in 1994.

\section{Terms of trade}

Neither exchange rate movements nor defective governance explains why the prices of the exports of these countries fell between 1995-1997. A more convincing reason for the slowdown in export earnings is that the markets for East Asian exports were being saturated. At the speed with which exports had been growing, saturation could only have been prevented by rapid diversification into new products. Comprehensive figures for prices of exports and imports are only available for Korea and they show that its terms of trade deteriorated by 27 per cent during the three years ending in September 1997. Its exports of a wide array of manufactures, including steel, cars, electronic goods and apparel were all affected. In electronic 
goods and appare1 Korea was competing against the Tier 2 economies, whose exports, diverse though they were, remained overwhelmingly concentrated in these two types of goods and in raw materials, and these economies experienced similar price declines and signs of market saturation.

\section{Failure of Policy}

The puzzle is why did the authorities of the East Asian economies, apart from Japan, not take steps to reduce domestic demand to prevent the current account deficits from growing when exports slowed, especially since the IMF had been warning the authorities in Thailand? Again a complete answer must wait for detailed studies. One possible reason is that, not having acted promptly at the first sign that export growth was below expectations, the authorities felt trapped. By that time short term liabilities to foreign investors had grown large in relation to reserves and so the authorities were loath to take steps that would have betrayed apprehension and undermined confidence in the viability of the balance of payments. At the time, the assumption that the slowdown of exports in 1995-96 was transitory and that the usual growth would resume the next year seemed reasonable, as shown by the belief expressed by prominent financiers, after the crisis had begun, as late as the end of September 1997, that it was only a passing storm and not likely to have serious consequences.

To this may be added overconfidence resulting from bad advice. The success of the East Asian economies had been widely and highly praised. Works such as the World Bank's "The East Asian Miracle" presented these economies, the Tier 2 economies in particular, in such a light as to seem to imply that the solution to economic development for all countries had been found. Such works have great influence, they are widely distributed among government officials and political leaders, who rarely have the time or the training to delve into debates among economists questioning the cogency of the analyses and therefore regard them as authoritative [For some of the many criticisms by established academic economists see Rodrik (a). Wade, etc.]. Since the dangers the economies face are not given much attention in such works, it is not surprising if those who make decisions on economic policy are unaware of or underestimate them.

If such works inspired a general feeling of invulnerability that may, in the last analysis, have been the most important cause of the crisis, they were also misleading on specific questions of policy. It was misleading to advocate the desirability of capital inflows without qualification and not to warn of the attendant risks. Sound macro-economic policies have been consistently presented as the sine qua non for the inflow of private capital, so it seemed to follow that the East Asian economies had nothing to worry 
about; they had consistently had modest budget deficits and low inflation not to mention high growth rates, and, the fact that private capital was flowing in was assurance that their economic policies must be correct and therefore, capital would continue to flow in.

Associated with this was the belief that portfolio capital inflow "severed the link between saving and investment", a belief that prove' especially pernicious by obscuring the distinction between loans with Ion maturity, which do in a sense have this effect, and "hot money'. If official truly believe that the link is severed, they see no point in converting incoming portfolio capital into reserves, which are a form of saving.

The World Bank's "East Asia Miracle" was misleading in another respect, subtler but equally dangerous. It ignored the distinction to be found in most other writings on the East Asian economies, between the Tier I and Tier 2 economies. By grouping together all the East Asia) economies discussed here, with the exception of the Philippines, it could draw conclusions that would not otherwise have been possible. Economist have criticised this as sleight of hand, and it obscured some difference between the two sets of economies that ought, instead, to have been emphasised to show the Tier 2 economies to what they should next direct their efforts.

Two differences were crucial. One was the caliber of the civil service, which is taken to cover the whole administrative system, including the judicial system and specialists in government agencies and ministries These are the backbone of any good system of governance. The second was the emphasis on education. Although the Tier 2 economies had made great progress in primary and secondary education, they still depended heavily oil foreign investors to train their labour and for the higher level skills needed for research and design functions. FDI allowed the economies to develop] quite far, but, in the final analysis, it was a gimmick. It worked well for a while, but did not remove the need for establishing the prerequisites for a well functioning society. 


\section{References}

Aitken, Brian, and Harrison, Ann, 1994. "Do Domestic Firms Benefit from Foreign Direct Investment? Evidence from Panel Data." Policy Research Working Paper 1248. Policy Research Department, World Bank.

Bergsten, Fred, 1997. "The Asian Monetary Crisis: Proposed Remedies." Statement Before the Committee on Banking and Financial Services, U.S. House of Representatives. November 13.

Bhaduri, Amit, 1996. "Implications of Globalisation for Macroeconomic Theory and Policy." Paper presented at the Conference on Globalisation and Progressive Economic Policy. Economic Policy Institute. Washington.

Claessens, Stijn, and Naude, David, 1993. "Recent Estimates of Capital Right.” Policy Research Working Paper No. 1186. World Bank.

Dornbusch, Rudi, 1997. "Cross-Border Payments, Taxes and Alternative Capital-Account Regimes.” In International Monetary and Financial Issues for the 1990s. Vol. VIII. UNCTAD.

Feldstein, Martin. "Refocusing the IMF." Foreign Affairs March/April 1998.

Fischer, Stanley. "Capital Account Liberalisation and the Role of the IMF." Presented on September 19th, 1997, in Hong-Kong, China, in conjunction with the annual meetings of the IMF and the World Bank.

Gereffl, Gary, 1997. "The Reorganisation of production on a World Scale: States, Markets and Networks in the Apparel and Electronics Commodity Chains." In Regionalisation and Labour Market Interdependence in East and South East Asia. Duncan Campbe11, Aurelio Parisotto, Anil Verma, Asma Lateef, eds. International Institute for Labour Studies, Geneva. MacMillan and St. Martin's Press.

Greenspan, Alan. Testimony Before the Committee on Banking and Financial Services, U.S. House of Representatives. January 30, 1998.

Henderson, Jeffrey, 1997. "The Changing International Division of Labour in the Electronics Industry." In Regionalisation and Labour Market Interdependence in East and South East Asia. Duncan Campbell, 
44 The Lahore Journal of Economics, Vol.3, No.1

Aurelio Parisotto, Anil Verma, Asma Lateef, eds. International Institute for Labour Studies, Geneva. MacMillan and St. Martin's Press.

Japan Development Bank and Japan Economic Research Institute, 1994. Several authors. "Policy-Based Finance. The Experience of Postwar Japan.” World Bank Discussion Papers, No. 221.

Krugman, Pau1, 1998. "Fire-Sale FDI. What Happened to Asia?"

Lee, Jang-Yung, 1997. "Sterilising Capital Inflows." Economic Issues No. 7. International Monetary Fund.

Lewis, W. Arthur, 1977. "The Evolution of the International Economic Order." Eliot Janeway Lecture in Historical Economics in Honour of Joseph Schumpeter. Princeton University Press.

Maddison, Angus, 1989. "The World Economy in the Twentieth Century." OECD.

Nayyar, D., 1995. "Globalisation: the Past in our Present."

Robinson, Joan, 1996. The New Mercantilism. An Inaugural Lecture. Cambridge University Press.

Rodrik, Dani. (a) "King-Kong Meets Godzilla: the World Bank and The East Asian Miracle" 1994. Centre for Economic Policy Research. Discussion Paper Series; No. 944:1-[?1]. London.

Rodrik, Dani. (b), 1997. "Has Globalisation Gone Too Far?" Institute for International Economics.

Rowthorn, R.E., and Wells, J.R., 1987. De-industrialization and Foreign Trade. Cambridge University Press.

Skeldon, Ronald, 1997. "Hong-Kong and Coastal China Growth Linkages." In Regionalization and Labour Market Interdependence in East and South_East Asia. Duncan Campbell, Aurelio Parisotto, Anil Verma, Asma Lateef, eds. International Institute for Labour Studies, Geneva. MacMillan and St. Martin's Press.

Trefler, 1993. Journal of Political Economy.

UNCTAD. Trade and Development Report 1996 
UNCTAD. Trade and Development Report, 1997. "Globalisation, Distribution and Growth.”

Vittas, Dimitri, and Kawaura, Akihiko, 1995. "Policy-Based Finance, Financial Regulation, and Financial Sector Development in Japan." Policy Research Working Paper 1443. Financial Sector Development Department. World Bank.

Vittas, Dimitri, and YoonJe Cho, 1995. "Credit Policies. Lessons from East Asia." Policy Research Working Paper 1458. Financial Sector Development Department. World Bank.

Wade, Robert, and Veneroso, Frank. "The Asian Financial Crisis: the Unrecognised Risk of the IMF's Asia Package."

Wade, Robert, 1990. "Governing the Market. Economic Theory and the Role of Government in East Asian Industrialisation.” Princeton.

World Bank. (b) "The East Asian Miracle. Economic Growth and Public Policy.” 1993. A World Bank Policy Research Report. Oxford.

World Bank. (c) 1997. "Private Capital Flows to Developing Countries. The Road to Financial Integration."

World Bank. (a) Global Development Finance 1998. Analysis and Summary Tables.

World Bank. (d) Global Development 1997. Analysis and Summary Tables.

Yoon Je Cho and Hellmann, Thomas, 1993. "The Government's Role in Japanese and Korean Credit Markets. A New Institutional Economics Perspective," Policy Research Working Paper 1190. Financial Sector Development Department. World Bank.

Yoon Je Cho and Kirn, Joon-Kyung, 1995. "Credit Policies and the Industrialisation of Korea.” World Bank Discussion Papers, No. 286. 